STUDI MANAGERIA: JURNAL MANAJEMEN PENDIDIKAN ISLAM

Volume 1, Nomor 1, Juni 2019

http://jurnal.radenfatah.ac.id/index.php/studiamanageria

\title{
Penerapan Manajemen Personalia di Madrasah Tsanawiyah Pondok Pesantren Qodratullah
}

\author{
Aditya Novali \\ Madrasah Tsanawiyah Pondok Pesantren Qodratullah, Palembang, Indonesia \\ adityanovali943@gmail.com
}

\begin{abstract}
This study aims to determine how the management of education by implementing personnel management in the Madrasah Tsanawiyah Islamic Boarding School Qodratullah Langkan Banyuasin III District, Banyuasin Regency. The type of research used is field research using a qualitative approach. The data used are of two kinds namely primary data sources and secondary data. Data collection techniques using observation, documentation and interviews. The collected data were analyzed using qualitative data analysis. The findings of this study are that the application of education management has been carried out quite well, in accordance with the conditions of the Islamic Boarding School Qodratullah Islamic Boarding School. This means that all of the management applications have been carried out but due to limited supporting factors in the form of infrastructure and the state of school personnel, the application of management is carried out to the extent of existing management. From the results of this study also showed that the concept of acceptance of professional educators, proper placement of personnel, and unfavorable personnel welfare must always be considered, because it is very influential in the development of the Qodratullah Islamic Boarding School in Banyuasin, South Sumatra. This concept needs to be empowered and developed especially in improving the management of learning in the Qodratullah Islamic Boarding School.
\end{abstract}

\section{Keywords: management, personnel}

Abstrak. Penelitian ini bertujuan untuk mengetahui bagaimana pengelolaan pendidikan dengan diterapkannya manajemen personalia di Madrasah Tsanawiyah Pondok Pesantren Qodratullah Langkan Kecamatan Banyuasin III, Kabupaten Banyuasin. Jenis penelitian yang digunakan adalah penelitian lapangan (field research) dengan menggunakan pendekatan kualitatif. Data yang digunakan ada dua macam yaitu sumber data primer dan data sekunder. Teknik pengumpulan data menggunakan observasi, dokumentasi dan wawancara. Data yang terkumpul dianalisis menggunakan analisa data kualitatif. Temuan penelitian ini adalah penerapan manajemen pendidikan telah dilaksanakan cukup baik, sesuai dengan kondisi Madrasah Tsanawiyah Pondok Pesantren Qodratullah. Artinya bahwa semua penerapan manajemen tersebut telah dijalankan namun karena keterbatasan faktor pendukunganya berupa sarana prasarana dan keadaan personil sekolah, maka penerapan manajemen tersebut dilaksanakan sebatas manajemen yang ada. Dari hasil penelitian ini juga menunjukkan bahwa konsep penerimaan pendidik yang professional, penempatan personalian yang tepat, dan kesejahteraan personalia yang kurang baik harus selalu diperhatikan, karena sangat berpengaruh terhadap perkembangan pesantren Qodratullah Langkan Banyuasin Sumatera Selatan. Konsep ini perlu diberdayakan dan dikembangkan terutama dalam meningkatkan manajemen pembelajaran di Pesantren Qodratullah.

Kata Kunci: manajemen, personalia 


\section{PENDAHULUAN}

Dalam Pendidikan nasional saat ini dituntut mampu menjamin pemerataan kesempatan pendidikan, peningkatan mutu dan relevansi serta efisiensi manajemen pendidikan. Pemerataan kesempatan pendidikan diwujudkan dalam program wajib belajar 9 tahun. Peningkatan mutu pendidikan diarahkan untuk meningkatkan kualitas manusia Indonesia seutuhnya melalui olahhati, olahpikir, olahrasa dan olahraga agar memiliki daya saing dalam menghadapi tantangan global. Dalam sebuah kuliah, Prof. Jalaluddin membagi peradaban manusia saat ini menjadi dua yaitu era global dan millenium III. Keduanya memiliki ciri tersendiri. Menurutnya, ciri tersebut yaitu; era global bersifat mendunia, kemajuan Iptek yang ditandai dengan komunikasi dan transformasi, materialistis, unggulan (kompetitif, komperatif dan profesional). Sedangkan millenium III ditandai dengan adanya perubahan sistem nilai berupa ideologi, tradisi dan agama (Sabtu, 30 April 2011. IAIN Raden Fattah). Setiap perubahan akan memunculkan kebutuhan dan tantangan baru, yang jika tidak diantisipasi dapat membuat kita hidup dalam situasi serba tak terduga (Atmowidiryo, 2000: 77).

Kemajuan suatu kebudayaan bergantung kepada cara kebudayaan tersebut mengenali, menghargai, dan memanfaatkan sumber daya manusia dan hal ini berkaitan erat dengan kualitas pendidikan yang diberikan kepada anggota masyarakatnya dan kepada peserta didik (Munandar, 1999: 6). Penyelenggaraan pendidikan di Indonesia dilakukan dalam tiga jalur yaitu, pendidikan formal, pendidikan non formal, dan pendidikan informal. Hal ini disuratkan dalam undang-undang Nomor 20 Tahun 2003 tentang Sistem Pendidikan Nasional pasal 1 ayat 10,11, 12 dan 13. Ayat 10 berbunyi "Satuan pendidikan adalah kelompok layanan pendidikan yang menyelenggarakan pendidikan pada jalur formal, non formal, dan informal pada setiap jenjang dan jenis pendidikan. "Ayat 11 "Pendidikan formal adalah jalur pendidikan yang terstruktur dan berjenjang yang terdiri atas pendidikan dasar, pendidikan menengah, dan pendidikan tinggi. " Ayat 12 "Pendidikan di luar Pendidikan formal yang dapat di laksanakan secara terstruktur dan berjenjang." Ayat 13 "Pendidikan informal adalah jalur pendidikan keluarga dan lingkungan." Diperuat lagi dengan ditetapkannya Undang-undang Sistem Pendidikan Nasional Nomor 20 Tahun 2003 Pasal 17 Ayat 2 yang menyatakan "Pendidikan Dasar Berbentuk Sekolah Dasar (SD) dan Madrasah Ibtidaiyah (MI) atau bentuk lain yang sederajat serta Sekolah Menengah Pertama (SMP) dan Madrasah Tsanawiyah (MTs), atau bentuk lain yang sederajat." Madrasah Tsanawiyah ditetapkan sebagai Sekolah Menengah 
(Penerapan Manajemen Personalia Di Madrasah Tsanawiyah Pondok Pesantren Qodratullah)

Pertama yang berciri khas Agama Islam yang diselenggarakan oleh Kementerian Agama.

Sejalan dengan itu, dalam kurikulum di Pondok Pesantren Qodratullah diberikan bahan kajian dan mata pelajaran yang menjadi ciri khas Madrasah, yaitu mata pelajaran Agama Islam yang diperluas (Saleh, 2000: 115). Dengan kesamaan bahan kajian dan mata pelajaran tersebut, secara akademis kualitas lulusan Pondok Pesantren Qodratullah diharapkan dapat sejajar dengan lulusan sekolah umum. Siswa di Pesantren Qodratullah diharapkan dapat memiliki kesempatan yang sama dengan lulusan sekolah umum untuk meneruskan pendidikan ke jenjang yang lebih tinggi maupun ke dunia kerja. Banyak faktor yang mempengaruhi tidak optimalnya mutu pendidikan tersebut, salah satunya adalah manajemen Personalia. Disadari atau tidak manajemen personalia yang sentralistik selama ini telah ikut bertanggung jawab terhadap terbentuknya output yang tidak relevan dengan perkembangan zaman. Karena manajemen personalia yang sentralistik cendrung mengakibatkan kreatifitas sekolah menjadi "mandeg". Padahal sekolah yang paling mengetahui kondisi yang dihadapi di lapangan. Dari segi kualitas pembelajaran, komponen yang dirasakan sangat perlu ditingkatkan adalah memfungsikan manajemen personalia, kemudian menerapkan metodologi dan teknologi pengajaran, kemampuan meningkatkan motivasi dan semangat belajar, serta kemampuan mengembangkan kreatifitas tenaga kependidikan terutama guru dalam kegiatan belajar mengajar. Berbagai usaha telah dilakukan untuk meningkatkan mutu pendidikan, antara lain dengan mengadakan berbagai pelatihan dan peningkatan kualifikasi guru, pengadaan buku dan alat pengajaran, perbaikan sarana dan prasarana pendidikan yang tidak kalah pentingnya adalah pendidikan mutu manajemen personalia di sekolah. Rendahnya mutu lulusan suatu Madrasah Tsanawiyah di Pondok Pesantren Qodratullah penyebabnya terletak pada tiga unsur pokok dalam proses pembelajaran yaitu, unsur kurikulum, unsur sumber daya pendidikan, dan unsur kualitas pembelajaran (Fajar 1998: 76). Unsur kurikulum yang dimaksud adalah kurikulum riil yaitu bahan kajian yang diberikan oleh guru kepada siswanya, baik di dalam maupun di luar kelas. Kelemahan kurikulum riil ini tidak hanya pada kemampuan guru dan fasilitas belajar, tetapi juga oleh kurikulum tertulis itu sendiri yang pada dasarnya pengamatan dan dianggap terlalu sarat, kurang fungsional, tidak proposional dan sebagainya. Kurang berhasilnya pendidikan tidak terlepas dari kelemahan faktor utama dalam proses di dalam kelas yaitu kelemahan guru dalam mengemas dan mendesain serta membawakan mata pelajaran kepada peserta didik. Ditambah lagi disebabkan ketiadaan penguasaan manajemen 
modern bagi guru (pelaksana pendidikan) dalam melaksanakan proses pembelajaran di sekolah, sehingga sulit dikontrol dan dievaluasi keberhasilan dan kegagalannya. Padahal quality control seharusnya menjadi pegangan dalam melaksanakan proses pendidikan sejak dari input proses sampai dengan output proses.

Manajemen merupakan suatu proses pendayagunaan segala sumber daya manusia dalam penyelenggaraan aktivitas dalam rangka mencapai tujuan secara efisien. Menurut Kast dan Rosenzweig, manajemen adalah proses perencanaan, pengorganisasian dan kegiatan pengawasan manusia dan benda ke arah tercapainya tujuan (Kast dan Rosenzweig, 1995: 6).

Dengan perkembangan sekarang ini pesantren itu menggunakan kiatkiat manajemen dan pola-pola kepemimpinan yang spesifik dan menarik untuk dicermati memiliki perhatian yang cukup terhadap personalia. Personalia adalah unsur yang mendukung perkembangan pesantren, personalia yang dimaksud dalam penilitian ini adalah guru madrasah di Pesantren Qodratullah. Masalah manajemen personalia di lembaga-lembaga pendidikan Islam seperti pesantren, kurang mendapat perhatian yang serius, karena masih terlalu berpegang teguh kepada konsep-konsep tradisonal seperti adanya konsep pengabdian atau ubudiyah, dan keikhlasan.

Di samping permasalahan yang disebutkan di atas, bagi Madrasah di Pondok Pesantren Qodratullah yang berada di bawah naungan Kementerian Agama, masih dijumpai beberapa masalah antara lain: Input rendah bila ditinjau dari standar ujian nasional maupun dari segi sosial ekonomi, serta latar belakang pendidikan orang tua murid. Tenaga kependidikan baik guru maupun tenaga administrasi yang kurang profesional. Ilmu manajemen apabila dipelajari secara komprehensif dan ditetapkan secara konsisten memberikan arah yang jelas, langkah yang teratur dan keberhasilan dan kegagalan dapat mudah dievaluasi dengan benar, akurat dan lengkap sehingga dapat dijadikan bahan pembelajaran bagi tindakan selanjutnya. Dalam rangka mencermati dan mencari sebuah pola alternatif dalam menuju terciptanya sebuah sistem atau pola manajemen pembelajaran di pesantren yang sesuai dengan kondisi perubahan ilmu pengetahuan. Peneliti mencoba memilih pondok pesantren Qodratullah Langkan Banyuasin Sumatera Selatan sebagai objek penelitian tesis ini. Karena dalam kepemimpinan Kyai atau yang biasa disebut Buya dalam mengatur Ustad dan Santri, dan Manajemen Pendidikan di pondok Pesantren Qodratullah belum berjalan dengan baik, sehingga perkembangan pondok Pesantren Qodratullah Langkan belum cepat berkembang seperti Pondok Pesantren Moderen lainnya, kemudian dari sarana dan prasarana yang kurang memadai dalam 
(Penerapan Manajemen Personalia Di Madrasah Tsanawiyah Pondok Pesantren Qodratullah)

sebuah proses pendidikan. (Wawancara Ust Harison, kepala Madrasah Tsanawiyah, 30 September 2014).

Dengan perkembangan sekarang ini pesantren Madrasah di Pondok Pesantren Qodratullah menggunakan kiat-kiat manajemen Personalia yang spesifik dan menarik untuk mencermati dalam mengubah proses manajemen pendidikan yang lebih baik lagi, yaitu dari perkembangan personalia yang baik, santri dan sarana prasarana yang memadai. Di Pondok Pesantren Qodratullah yang terletak di desa Langkan kecamatan Banyuasin III kabupaten Banyuasin, yang dalam hal ini akan diteliti adalah lembaga pendidikan menengah pertama yang bercirikan Islam yang selalu berusaha meningkatkan kualitas output nya di tengah persaingan dengan lembagalembaga pendidikan menengah pertama lainnya.

Sejalan dengan perkembangan zaman, tantangan yang dihadapi Madrasah Pesantren Qodratullah semakin kompleks, mencakup seluruh kegiatan dalam pembentukkan manajemen personalia yang baik. Permasalahan utama yang muncul yaitu rendahnya minat siswa untuk masuk ke Madrasah Pesantren Qodratullah ini. Sebenarnya hal ini cukup bisa dimaklumi karena persaingan antara sekolah-sekolah menengah pertama lainnya baik yang berstatus negeri atau swasta sangatlah menonjol. Selain masalah tadi, sebenarnya masih banyak masalah lain seperti terbatasnya sarana dan prasarana pendidikan, kualitas sumber daya manusia yang masih rendah atau input yang masih rendah, seperti nilai ujian yang kecil, ada yang tidak lulus ujian nasional, dan ada yang tidak dapat mengamalkan ilmunya di masyarakat dan lain-lain. Oleh karena itu, penelitian ini berjudul Manajemen Personalia di Madrasah Tsanawiyah Pondok Pesantren Qodratullah Desa Langkan Kecamatan Banyuasin III, Kabupaten Banyuasin.

\section{KAJIAN LITERATUR}

Untuk melengkapi dasar penelitian yang akan dilakukan, penelitian didasarkan kepada beberapa penelitian yang pernah dilaksanakan. Dalam penelitian tentang Manajemen Pondok Pesantren Sulthon Masyhud dan Khusnurdilo dengan judul "Manajemen Pondok Pesantren". Dalam tulisan ini pernyataan Sulthon Masyhud dan Khusnurdilo masih bersifat menyeluruh atau umum belum terfokus tentang manajemen personalia pendidikan pondok pesantren, juga pernah ditulis oleh Hendra Zainudin, dalam tesisnya perbandingan manajemen pondok pesantren. Raudhotul Ulum Sakatiga Ogan Ilir dengan pondok pesantren Ittifaqqiyah Indralaya Ogan Ilir. Kemudian penelitian yang berjudul "Evaluasi Manajemen Pendidikan Madrasah Ibtidaiyah Yayasan Badan Amal Kesejahteraan Ittihadul Islamiyah Karang 
Jengkol Kesugihan Cilacap" hasil penelitian Zulfa (2013). Penelitian ini menunjukkan adanya beberapa faktor penghambat dalam proses pembelajaran khususnya di Madrasah antara lain, kualitas output cendrung naik turun, adanya kesulitan sekolah dalam bidang finansial sehingga banyak program sekolah yang mengalami hambatan dalam realisasinya, dan partisipasi masyarakat masih relative rendah walaupun menunjukkan adanya peningkatan. Selanjutnya penelitian dari Purza (2009) yang berjudul: "Manajemen Personalia Pendidikan di Pondok Pesantren Sabilul Hasanah, Desa Air Batu, Kec.Banyuasin III, Kab Banyuasin." Dalam penelitian ini disampaikan tentang personalia Madrasah Pondok Pesantren Sabilul Hasanah dalam meningkatkan mutu pendidikan dengan diterapkan metode manajemen tersebut.

Selanjutnya penelitian dari Muhammad Arkan Nurwahidin (2006) yang berjudul "Strategi Manajemen Madrasah Aliyah Model di Palembang dalam Meningkatkan Mutu Pendidikan." Dalam penelitian ini juga disampaikan bahwa di dalam strategi manajemen yang di terapkan di sekolah ini belum maksimal, dan setelah diterapkan metode manajemen yang baik dapat meningkatkan kualitas dan mutu pendidikan di Madrasah Aliyah Model di Palembang. Penelitian tentang Manajemen Pondok Pesantren Sulthon Masyhud dan Khusnurdilo dengan judul "Manajemen Pondok Pesantren". Dalam tulisan ini pernyataan Sulthon Masyhud dan Khusnurdilo masih bersifat menyeluruh atau umum belum terfokus tentang manajemen pendidikan dalam pembelajaran di pondok pesantren. Kemudian penelitian Mastuki dkk dengan judul "Manajemen Pondok Pesantren" dalam tulisan itu Mastuki mengemukakan manajemen kurikulum, santri dan keuangan dilihat secara umum. Dari tulisan ini masih belum tampak Manajemen Personalian dari penelitian itu.

Dalam buku yang berjudul Manajemen Pendidikan (Mengatasi Kelemahan Pendidikan Islam di Indonesia) karangan Prof. Dr. H. Abuddin Nata, M.A tahun 2008. Buku ini membahas tentang, berbagai isu kontemporer tentang pendidikan Islam, tantangan pendidikan Islam abad XXI, profesionalisme guru dan mubaligh, kualitas pendidikan yang islami, pendidikan dan moral bangsa, pendidikan kedewasaan berbeda pendapat, organisasi dan metodologi pengajaran, materi pokok pendidikan Islam. Dengan demikian, penelitian yang akan dilakukan berjudul "Penerapan fungsi Manajemen Pendidikan dalam Peningkatan Kualitas Pembelajaran pada Madrasah Tsanawiyah Pondok Pesantren Qodratullah Langkan Kecamatan Banyuasin III, Kabupaten Banyuasin" adalah penelitian yang baru dan sama sekali belum pernah diteliti oleh peneliti sebelumnya. 
Adapun teori yang mendukung penerapan manajemen personalia:

a. Teori Proses atau Expectancy adalah keputusan yang didasari oleh individu untuk bertindak dalam cara tertentu, nilai-nilai yang dianut oleh individu yang berhubungan dengan pemilihan hasil akhir yang dikehendakinya, harapan individu yang berhubungan dengan jumlah usaha yang diperlukan untuk mancapai hasil akhir dan harapan individu untuk diberi hadiah dalam mencapai hasil akhir yang diinginkan (Arif, 1986: 557).

b. Teori Psikologis (The Psykologis Theory). Teori ini menyatakan bahwa fungsi pemimpin adalah mengembangkan system motivasi terkait, serta merangsang bawahannya untuk bekerja keras pencapaian sasaran organisasi maupun memenuhi tujuan pribadi. Di samping itu kepemimpinan ini sangat memperhatikan pengakuan kepastian emosional dan kesempatan untuk memperhatikan kebutuhan dan keinginan bawahan (Winardi, 2000: 36).

\section{METODE PENELITIAN}

Penelitian itu dilaksanakan di Madrasah Tsanawiyah Pondok Pesantren Qodratullah Langkan Kecamatan Banyuasin III, Kabupaten Banyuasin. Penelitian ini adalah penelitian lapangan (field research) dengan menggunakan pendekatan kualitatif. Jenis data yang digunakan adalah data kualitatif. Sumber data yang digunakan ada dua macam yaitu sumber data primer dan data sekunder. Sedangkan untuk mendapatkan datanya dengan menggunakan metode observasi, dokumentasi dan wawancara. Dalam pengelolaan data menggunakan analisa data kualitatif.

\section{HASIL DAN PEMBAHASAN}

Manajemen personalia dalam pondok pesantren Qodratullah Langkan merupakan unsur yang sangat penting, masalah ini telah menarik perhatian para pakar pendidikan sejak dahulu. Masyhud dan Khusnurdilo (2003:16) menuliskan bahwa hubungan personalia di pesantren yang begitu dekat tidak bisa diganti dengan hubungan impersonal seperti berlaku dalam manajemen modern. Hubungan kyai-satri, atau kyai dengan masyarakat selama ini terbangun dari hubungan personal dan spiritual. Bantuan masyarakat yang diberikan kepada pesantren kerap kali tanpa ada perjanjian hitam di atas putih alias ikhlas dan lillahi ta'ala.

Dalam hal ini kyai perlu ada pembantu dalam menyelesaikan tugastugas yang sangat banyak dalam mengelolah pondok pesantren Qodratullah langkan. Seorang kyai tidak mungkin melakukan segala bidang kegiatan 
mencapai tujuan yang diinginkan, karena mempunyai keterbatasan dalam hal fisik maupun psikisnya. Orang tidak mungkin bekerja siang dan malam tanpa tidur, istirahat dan sebagainya, selain daripada itu pengetahuan seseorang pun terbatas. Untuk mengelolah manajemen personalia pondok pesantren diperlukan bermacam-macam bidang pengetahuan dan keterampilan. Dengan adanya keterbatasan yang dipunyai oleh seseorang pemimpin maka perlu diadakan pendelegasian wewenang kepada orang lain guna memungkinkan menggerakkan personalia dalam lembaga pendidikan seperti pesantren.

Pendapat Arif (1986: 332) bahwa delegasi wewenang adalah suatu proses yang terjadi dalam manajemen seorang atasan memberikan wewenang kepada bawahan untuk melakukan tugas-tugas tertentu. Dalam proses pendelegasian wewenang berjalan setingkat demi setingkat mulai tingkat atas sampai ke tingkat terendah. Pendapat yang dikutif oleh Arif (1986: 332) dalam tulisan Newman adalah ada tiga peristiwa dalam proses pemberian wewenang pertama: menunjukkan atau memberikan tugas-tugas tertentu untuk dikelolah oleh bawahan, kedua: memberi izin kepada bawahan untuk membuat perjanjian, menggunakan sumber-sumber yang tersedia, dan mengambil keputusan dan tindakan tertentu dalam batas tugas yang telah didelegasikan kepada bawahan, ketiga : menciptakan tanggung jawab bagi setiap baawahan yang menerima pendelegasian terhadap atasannya untuk melaksanakan tugas itu dengan sebaik-baiknya. Pendapat Masyhud dan Khusnurdilo (2003:24) dalam tulisan Fiedler adalah lebih melihat individu dalam kelompok yang diberi tugas untuk mengarahkan dan mengkoordinasikan aktifitas-aktifitas kelompok yang terkait dengan tugas. Dikuatkan oleh sebuah teori: teori Supportif, pemimpin beranggapan bawahan ingin berusaha sebaik-baiknya dan bawahan dapat memimpin dengan sebaik-baiknya melalui tindakan membantu usaha-usaha mereka intinya adalah pemimpin berusaha memberikan kepercayaan pada bawahannya seluas-luasnya, bekerjasama dengan pihak lain, serta mengembangkan skillnya dan kepemimpinannya sendiri. Teori ini sering juga disebut dengan teori "Patisipatif" atau juga ada yang menyebutnya dengan "Democratic Theory of Leadershif". Winardi (2000: 36). Di dalam pemberian wewenang kepada Madrasah, anggota yayasan dan wakil pimpinan pesantren, seorang pimpinan pesantren harus mengatur personalia dengan baik. Manajemen personalia yang dimaksud dalam penelitian adalah proses menerima personalia (guru) dalam menempatkan sesuai dengan bidang keahlian, meningkatkan mutu, dan memberikan kesejahteraan. Proses penerimaan personalia sebagaimana metode yang 
(Penerapan Manajemen Personalia Di Madrasah Tsanawiyah Pondok Pesantren Qodratullah)

lazim digunakan yang diungkapkan oleh Heidjrachman dan Husnan (1997:45). Tahap pertama, wawancara pendahuluan, pengisian formulir/blanko, memeriksa referensi, test psikologi dan persetujuan atasan diterima atau tidak, artinya bahwa pelamar yang lolos dari langkah-langkah sebelumnya, sampailah pada langkah terakhir adalah persetujuan atasan. Persetujuan atasan sesuai dengan prinsip hubungan "line" dan "staff".

Tahap kedua adalah menempatkan personalia sesuai dengan bidang keahlian yang dimiliki oleh personalia (guru). Penempatan personalia yang tidak tepat akan menentukan berhasil atau tidaknya suatu usaha dan berakibat fatal bagi suatu kegiatan. penempatan personalia sesuai dengan bidang keterampilan yang dimiliki adalah hal yang utama dalam memajukan suatu organisasi akan tetapi tidak berhenti sampai disitu saja untuk mencapai keberhasilan yang lebih baik perlu ada pelatihan-pelatihan yang diikuti oleh personalia agar supaya menjadi lebih professional lagi, sebagaimana pendapat Haidjrachman dan Husnan (1997: 71) latihan-latihan yang diberikan kepada para personalia akan mendorong personalia bekerja lebih keras. Hal ini disebabkan karena personalia telah mengetahui dengan baik tugas dan tanggung jawabnya akan mencapai tingkat moral kerja yang lebih tinggi. Hal yang sama diungkapkan oleh Arif (1986: 517) Ilmu pengetahuan dewasa ini semakin modern akibatnya masyarakat semakin maju pula sehingga segala sesuatunya cepat berubah. Supaya dapat memberikan pelayanan yang lebih terampil dan meningkatkan mutunya maka setiap personalia perlu mengikuti pendidikan dan latihan sehingga tidak ketinggalan zaman. Pendidikan dan latihan itu harus dilakukan harus terus-menerus sesuai dengan perkembangan zaman.

Tahap ketiga adalah kesejahteraan personalia, sebagian kondisi kerja dapat menciptakan tingkat motivasi yang tinggi sehingga dapat mendorong semangat personalia untuk melaksanakan tugas secara maksimal sehingga hasil terus meningkat faktor ini bersumber pada pekerjaan itu sendiri. Orang berusaha karena usaha tersebut menghasilkan pekerjaan dan pekerjaan itu akan mendapatkan imbalan. Disamping itu ada kepentingan, kekuatan, nilai atau dorongan untuk mendapatkan insentif atau imbalan yang diharapkan seseorang untuk berusaha. Kemampuan, keterampilan serta pengetahuan seseorang ditambah dengan persepsi atau harapan-harapan yang nyata atau tersembunyi akan mempengaruhi pekerjaannya. Pendapat Arif (1986: 557) Pekerjaan itu akan menimbulkan kepuasan kalau individu memperoleh imbalan baik yang bersifat intrinsic (penghargaan, tanggung jawab, kegembiraan) maupun yang bersifat extrinsic (gaji, hadiah, dan bonus) kesemuanya itu diterima secara wajar tetapi kalau imbalan yang diterimanya 
tidak sesuai dengan apa yang diharapkan maka personalia itu akan frustasi dan tingkah lakunya akan malas.

Manajemen personalia lebih ditekankan oleh seorang pemimpin dalam menggerakkan dan mengelola sumber daya manusia pada santri Madrasah di Pesantren Qodratullah untuk mencapai tujuan pendidikan secara efisien dan efektif. Pengertian ini lebih bersifat operasional, yang mengarah kepada pemanfaatan sumber daya yang tersedia dalam mencapai tujuan yang telah ditetapkan.

Hardjooedarmo (1999: 13) menyatakan bahwa kerangka dasar manajemen meliputi: "Philosophy, assumptions, principles, and theory, which are basic to the study of any discipline of management". Secara sederhana dikatakan bahwa falsafah merupakan pandangan atau persepsi tentang kebenaran yang dikembangkan dari berpikiran praktis.

Bagi seorang manajer falsafah merupakan cara berfikir yang telah terkondisikan dengan lingkungan, perangkat organisasi, nilai-nilai dan keyakinan yang mendasari tanggung jawab seorang manajer. Falsafah seorang manajer dijadikan dasar untuk membuat asumsi-asumsi tentang lingkungan, peran organisasinya, dan dari asumsi ini lahir prinsip-prinsip yang dihubungkan dengan kerangka atau garis besar untuk bertindak.

Seperangkat prinsip yang berkaitan satu sama lain dikembangkan dan diuji dengan pengalaman sebelum menjadi suatu teori. Untuk seorang manajer, suatu teori tentang manajemen sangat berfungsi dalam memecahkan masalah-masalah yang timbul.

Oleh karena itu falsafah, asumsi, prinsip-prinsip, dan teori tentang manajemen merupakan landasan manajerial yang harus dipahami dan dihayati oleh manajer. Oleh sebab itu proses ini selanjutnya akan dipergunakan sebagai kerangka teori untuk mencermati manajemen personalia di Madrasah di Pondok Pesantren Qodratullah Langkan Kecamatan Langkan Kabupaten Banyuasin III.

Dalam penelitian ini akan bersandar pada standar mutu pendidikan yang meliputi: Pertama input baik yang menyangkut sumber daya manusia dalam melaksanakan kebijakan mutu personalia sekolah yang dapat diukur dari tingkat kesiapan input. Semakin tinggi tingkat kesiapan sumber daya, semakin tinggi pula upaya dalam meningkatkan prestasi sekolah. Kedua, proses pendidikan yang menyangkut manajemen personalia seperti yang telah disebutkan sebelumnya, dan ketiga output, maksimal dari hasil tes kemampuan akademik santri berupa nilai ulangan umum, nilai Ujian Akhir Nasional (UAN), dan Ujian Masuk Perguruan Tinggi (UMPTN) dan dari 
$\overline{\text { prestasi bidang lain seperti : prestasi kesenian, olahraga, dan keterampilan di }}$ tingkat sekolah.

Temuan dalam penelitian ini adalah penerapan manajemen pendidikan telah dilaksanakan cukup baik, sesuai dengan kondisi Madrasah Tsanawiyah Pondok Pesantren Qodratullah. Artinya bahwa semua penerapan manajemen tersebut telah dijalankan namun karena keterbatasan faktor pendukunganya berupa sarana prasarana dan keadaan personil sekolah, maka penerapan manajemen tersebut dilaksanakan sebatas manajemen yang ada.

Dari hasil penelitian ini juga menunjukkan bahwa konsep penerimaan pendidik yang professional, penempatan personalian yang tepat, dan kesejahteraan personalia yang kurang baik harus selalu diperhatikan, karena sangat berpengaruh terhadap perkembangan pesantren Qodratullah Langkan Banyuasin Sumatera Selatan, konsep ini perlu diberdayakan dan dikembangkan terutama dalam meningkatkan manajemen pembelajaran di Pesantren Qodratullah.

\section{KESIMPULAN DAN SARAN}

Setelah dilakukan pembahasan dari hasil penelitian yang berkaitan dengan masalah pokok, yaitu penerapan manajemen personalia dalam peningkatan kualitas pembelajaran pada Madrasah Tsanawiyah Pondok Pesantren Qodratullah Langkan Kabupaten Bnayuasin maka dapat dibuat kesimpulan sebagai berikut : Pertama, cara penerimaan personalia pendidikan di Pondok Pesantren Qodratullah dilakukan dengan prosedur manajemen modern dengan penilaian yang objektif berdasarkan seleksi dan musyawarah. Pelamar yang diterima ditempatkan sesuai dengan kecakapan, keterampilan dan kebutuhan personalia pesantren. Sebagian personalia pendidikan yang diterima itu merupakan lulusan pesantren Qodratullah Langkan Banyuasin Sumatera Selatan dan lulusan pesantren lain, pesantren Sri Bandung Ogan Komering ilir, Raudhotul Ulum Ogan Ilir dan Pondok Modern Darussalam Gontor Jawa Timur.

Kedua, dalam rangka pengembangan mutu, bimbingan, dan pengawasan profesionalitas tenaga pengajar, Pondok Pesantren Qodratullah telah menggunakan prinsip-prinsip modern, dilakukan melalui berbagai macam pendidikan dan latihan seperti pembekalan tentang tugas seorang guru (penataran guru), kegiatan pelatihan penyegaran (pelatihan pendalaman bahan ajar). Bimbingan bahan pelajaran (belajar kepada guru yang lebih mengetahui mengenai bahan ajar yang akan diajarkan kepada santri). Pengawasan secara umum, dengan musyawarah rutin setiap bulan, permasalahan atau kesenjangan yang timbul selama satu bulan proses 
belajar mengajar dibahas dan diselesaikan, penanaman segi ubudiah oleh pimpinan pesantren, hal demikian jarang terjadi di lembaga-lembaga sejenis ini, musyawarah bulanan melibatkan Asatidz wal Ustadzah.

Ketiga, dalam mengelola kesejahteraan personalia pondok pesantren Qodratullah, masih menggunakan paradigma lama, tetap memegang teguh aturan lama mengedepankan beribadah, didasarkan asas-asas ukhrowi, yaitu asas-asas yang dilandaskan kepada Pengabdian, ketakwaan, keikhlasan, dan barokah. Akan tetapi, pesantren telah berusaha untuk memberikan kesejahteraan dengan sebaik-baiknya dengan memberikan berbagai macam fasilitas, yakni beasiswa belajar di Timur Tengah, perguruan Negeri atau Swasta di Sumatera Selatan dan Jakarta, beras bagi yang berkeluarga, perkebunan karet, honorarium bulanan, dan fasilitas listrik, air bersih. Apabila dihitung jumlahnya, memang nilai nominal kesejahteraannya masih kurang apabila dibandingkan dengan kesejahteraan pegawai pemerintah, tetapi secara nilai ukhrawinya (kepuasan hati) jauh lebih besar nilainya dari pada nilai nominal. Karena didasarkan atas pengabdian, ketakwaan dan keikhlasan yang tulus, merupakan pedoman yang tetap dilestarikan di pondok pesantren Qodratullah karena salah satu tujuan dari pondok pesantren Qodratullah Langkan Banyuasin.

\section{DAFTAR PUSTAKA}

Arif, H.M. (1986). Filsafat Pendidikan Islam. Jakarta: PT Bina Aksara.

Atmowidiryo, S. (2000). Manajemen Pendidikan Indonesia. Jakarta: Ardadizjaya.

Fajar, M. (1998). Visi Pembaharuan Pendidikan Islam. Jakarta: LP3NI.

Hardjooedarmo dan Soewarso. (1999). Total Quality Management. Yogyakarta: Andi Offset.

Heidjrachman dan Suad, H. (1997). Manajemen Personalia. Yogyakarta: BPFE. Kast, F.E dan James E. R. (1995). Organisasi Dan Manajemen. Jakarta : Bumi Aksara.

Masyhud, S dan Khusnurdilo, M. (2003). Manajemen Pondok Pesantren. Jakarta: Diva Pustaka.

Munandar, U. (1999). Pengembanga Kreatifitas Anak Berbakat. Jakarta: Rineka Cipta.

Nata, A. (2008). Manajemen Pendidikan (Mengatasi Kelemahan Pendidikan Indonesia). Jakarta: Kencana Prenada Media Group.

Saleh, R. A. (2000). Pendidikan dan Keagamaan Visi, Misi dan Aks. Jakarta: Gemawindu Pancaperkasa.

Undang-Undang Nomor 20 Tahun 2003 tentang Sistem Pendidikan Nasional. 
Winardi. (2000). Kepemimpinan dalam manajemen. Jakarta: Rineka Cipta Zulfa, U. (2013). Membangun Madrasah bermutu Mellaui Praktik Manajemen Pembiayaan Pendidikan Berbasis Potensi Umat (Sebuah Alternatif Model Pembiayaan Pendidikan di Indonesia). Jurnal Kependidikan, 1 (1). 
